

\section{What Is a Nowcast and How Does It Work?}

A nowcast is like a weather forecast but instead of estimating future conditions, a nowcast estimates current conditions in real time. Mathematical models, operated within a web-based system, are the basis for these real-time assessments. Mathematical models are used to predict a single variable (known as the dependent variable, in this case $E$. coli or microcystin concentrations) from one or more environmental and (or) water-quality variables (known as the explanatory variables) that are easily and quickly measured, such as rainfall and water clarity (turbidity). Explanatory variables are used as surrogates to estimate concentrations of the dependent variable or the probability that a standard or action threshold will be exceeded.

\section{What Are the Data Requirements to Develop a Nowcast Model?}

The first step in implementing a nowcast is to collect enough data to develop a mathematical model for $E$. coli or cyanotoxin concentrations. Data should be collected during a minimum of two recreational seasons with a sample-col-

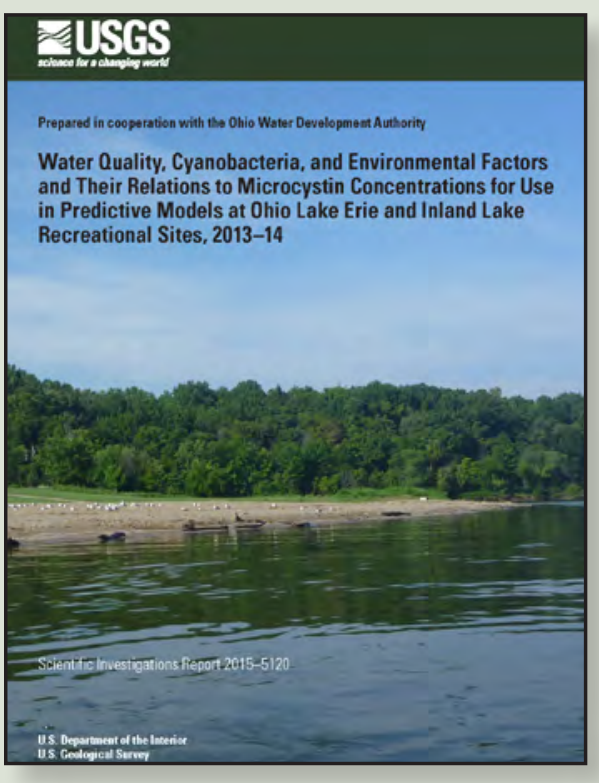

Francy and others, 2015. lection frequency of at least weekly and should include a range of environmental

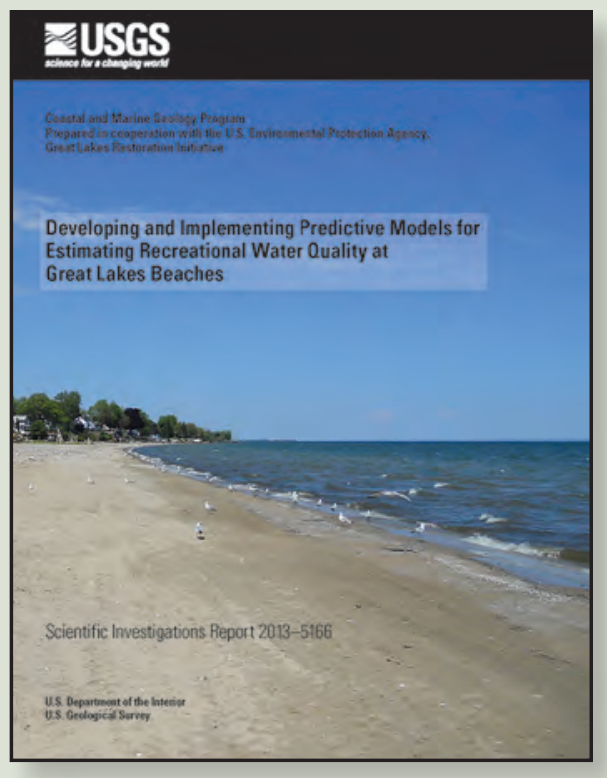

Francy and others, 2013. conditions. Samples for the dependent variable and any site-specific explanatory variables can be collected by the USGS and (or) local agencies. Continuously measured water-quality and environmental explanatory variables are compiled from existing sources. Below are common variables significantly correlated to E. coli and microcystin levels (Francy and others, 2013, 2015).

\section{E. coli}

- Turbidity

- Day of the year

- Wave height

- Antecedent rainfall for up to 3 days before sampling

- Wind speed and direction

- Change in lake level over 24 hours

\section{Microcystin}

- Phycocyanin fluorescence

- Chlorophyll fluorescence

- $\mathrm{pH}$

- Mean daily streamflow (nearby river)

- Cyanobacterial gene concentration

- Orthophosphate concentration

- Total nitrogen to total phosphorus ratios

\section{What Are the Steps for Nowcast Model Development, Testing, and Implementation?}

At the end of the second year of data collection, data on potential explanatory variables are compiled from existing sources for use in the models. The models can be developed using a free software package, Virtual Beach, designed by the U.S. Environmental Protection Agency (EPA) as a decision support tool. The EPA's Virtual Beach software is versatile and user friendly and can be used for data exploration, variable selection, and model development and validation (EPA, 2019). The model is tested (validated) during an independent third year of data collection. If the model performs well, the model may be used for management decisions during the following year. Beach advisories or closings based on model results are available to the public using signage at the site or through a public website.

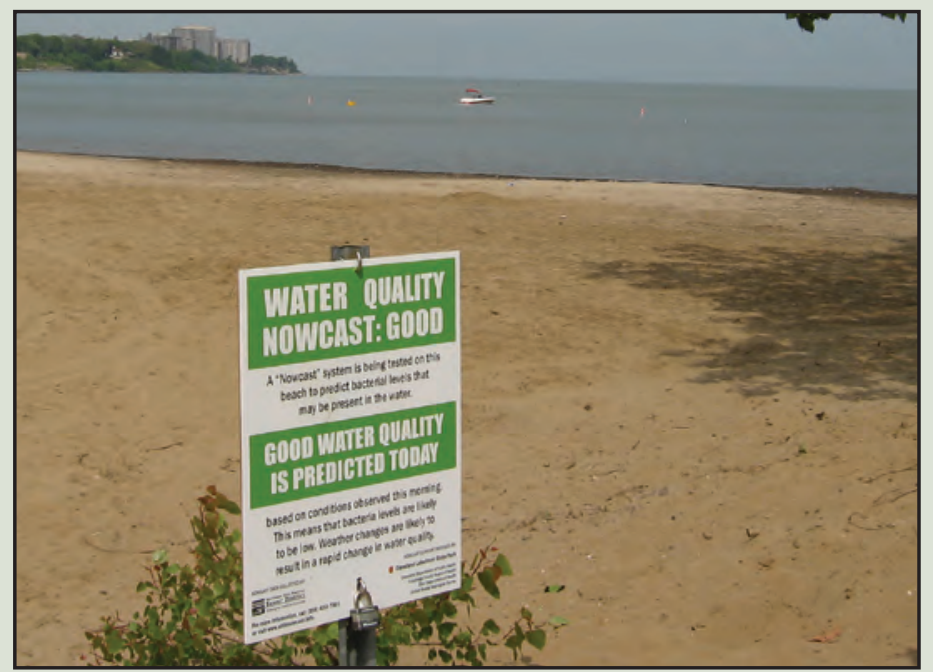

Sign showing results from a nowcast at Edgewater Beach, Cleveland, Ohio. Photograph by Donna Francy, U.S. Geological Survey. 


\section{What Are the Benefits of a Nowcast?}

Nowcasts benefit the public.-Nowcasts can inform the public of water-quality conditions at recreational sites in near-real time based on daily or "as needed" model results. Using the nowcast, the public can make a more informed decision on whether to visit and recreate at a site before traveling to the site. This option is not available to the public when traditional methods of determining water-quality conditions, which can take as long as 24 hours for results to be available, are used.

Nowcasts benefit water-resource managers.-Using model results, managers at recreational or drinking-water treatment plant sites can focus sample collection to times when $E$. coli or cyanotoxins are likely to be elevated. For recreational sites, managers can provide daily swimming advisories or boating advisories to the public. For drinking-water treatment plant sites, managers can use model results to optimize drinking-water treatment and (or) intake options for current conditions. Behind the scenes, nowcast systems provide speed and efficiency for managers by automating data management and standardizing methods among agencies.

\section{Operational Nowcast-The Great Lakes NowCast}

During 2019, operational nowcasts were available to the public for 25 beaches and 1 recreational river site (USGS, 2019). This multistate effort provides a single source for public notification and for partners to compile and manage data. Water-quality advisories based on models have been available through the Great Lakes NowCast website since 2006, 2013, and 2017 for sites in Ohio, New York, and Pennsylvania, respectively.

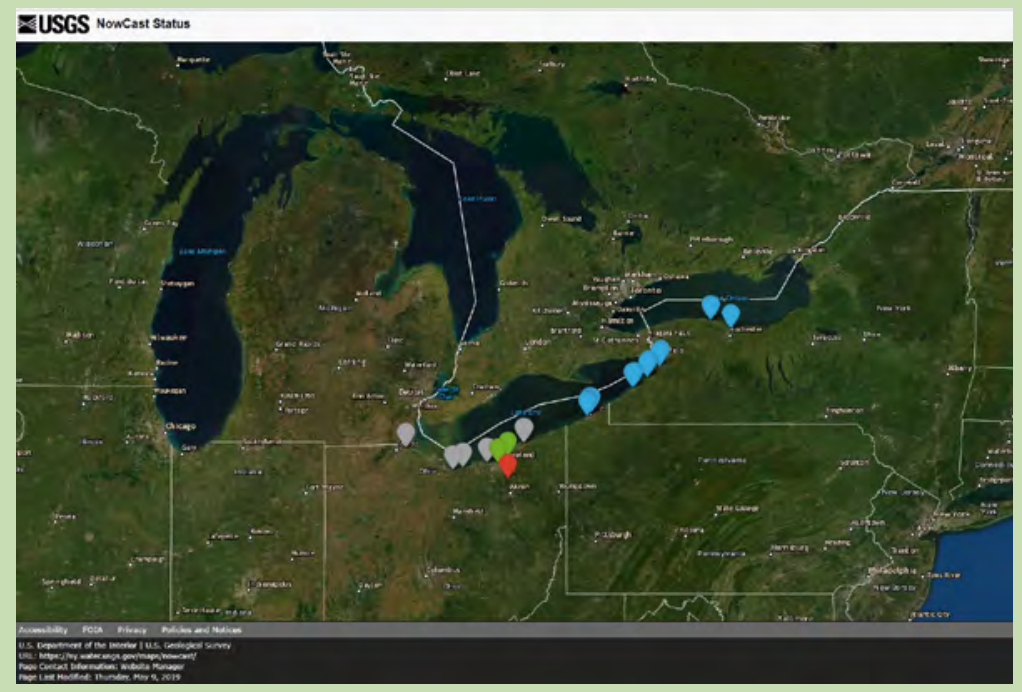

The Great Lakes NowCast is a public notification system and a data management system for beach managers (https://ny.water.usgs.gov/maps/nowcast/).
Public information, currently available for E. coli concentration estimates, includes advisory or closing notices, background information, model parameters, site information, and current data. Behind the scenes, beach managers enter field observations while available data are automatically harvested from online sources such as the National Weather Service, National Oceanic and Atmospheric Administration, and USGS. Data are easily exported to Virtual Beach for running the model daily or as needed.

\section{What Is Next for the Great Lakes NowCast?}

The USGS will continue to work with partnering agencies to refine and enhance the Great Lakes NowCast and include sites in other States and at inland lakes. Developing and testing site-specific models to estimate cyanotoxin (microcystin) concentrations to help with management decisions is in progress. Implementing the use of microcystin models through the USGS Great Lakes NowCast is the next step.

\section{What Training Is Available to Develop a Nowcast?}

The USGS has hosted five interagency hands-on workshops to develop mathematical models for recreational and drinkingwater treatment plant sites, the most recent in Troy, New York, in April 2019. Instructors and speakers from several USGS centers bordering the Great Lakes and the EPA National Exposure Research Laboratory are available to provide training on developing models for estimating $E$. coli and cyanotoxin concentrations.

"NowCast is a great use of scientific data to predict real-time water quality. The model has an impressively low error rate and provides critical information used to manage our beaches that receive millions of visitors annually."

Jeanette L. Schnars, Ph.D., Executive Director, Regional Science Consortium

Erie, Pennsylvania
"The work that USGS is doing with the NowCast is an important part of reducing the risk and fear that arises with treating the lake water during HAB [harmful algal bloom] season."

J. Kelly Frey, P.E., P.S., Ottawa County Sanitary Engineer Port Clinton, Ohio 


\section{How Well Does a Nowcast Perform as Compared to the Traditional Method for Determining Water-Quality Conditions?}

The nowcast model correctly predicted water-quality conditions below or above the water quality standard (WQS) 84.3 percent of the time and more often than the traditional method of using the $E$. coli concentration from the previous day. At Huntington Beach in Bay Village, Ohio, sample data and model results are available for 13 years - from 2006 through 2018. The nowcast model has also performed better than the traditional method in predicting when concentrations were below the WQS (specificity). This means that by using the nowcast model, there have been fewer instances when the beach is incorrectly posted with an advisory, which encourages visitors and potentially boosts the local economy because more visitors are recreating in the area. The most noticeable difference was with model sensitivity, which is how well each predictive tool correctly predicts exceedances of the WQS. From a public health standpoint, this is the most important statistic. The higher the sensitivity, the more often the predictive tool correctly predicts when there is an advisory and protects the public from contact with potentially contaminated water. By using the Great Lakes NowCast, beach managers at Huntington Beach have been able to protect public health and encourage use of the beach when it is safe to swim.

Nowcast model performance at Huntington Beach, Bay Village, Ohio: 2006-18

\begin{tabular}{ccccc}
\hline \multicolumn{1}{c}{ Predictive tool } & $\begin{array}{c}\text { Sample } \\
\text { size }\end{array}$ & $\begin{array}{c}\text { Correct } \\
\text { (in percent) }\end{array}$ & $\begin{array}{c}\text { Specificity } \\
\text { (in percent) }\end{array}$ & $\begin{array}{c}\text { Sensitivity } \\
\text { (in percent) }\end{array}$ \\
\hline $\begin{array}{l}\text { Nowcast model, E. coli } \\
\begin{array}{c}\text { Previous day's } \text { E. coli } \\
\text { concentration }\end{array}\end{array}$ & 1,186 & 84.3 & 89.2 & 62.7 \\
\hline
\end{tabular}

"Our laboratory at the Lake Erie Center has been monitoring densities of E. coli and the controlling environmental parameters at the Lake Erie beaches of Maumee Bay State Park for well over a decade. The NowCast system allows us to report when exceedances occur, providing two fantastic outcomes: (1) People check NowCast to determine whether to make a trip to the beach (as told to us by recreational users), and (2) we refer to NowCast in proposal writing to demonstrate a broader impact of our research.'

Daryl F. Dwyer, Ph.D., Department of Environmental Sciences The Lake Erie Center and The Stranahan Arboretum The University of Toledo, Ohio
"The use of NowCast predictions at our area beaches has allowed for accurate and timely results to be given directly to beach users almost instantaneously. Without the use of NowCast, we would still rely on a laboratory method to rate our beaches and this method takes a minimum of 18 hours to determine the rating at a beach. The timeliness and real time results from NowCast allows for a beach user to make a decision based on the most immediate data at the time."

Craig Ward, Registered Sanitarian, Director of Environmental Health Erie County Health Department Sandusky, Ohio

\section{References}

Francy, D.S., Brady, A.M.G., Carvin, R.B., Corsi, S.R., Fuller, L.M., Harrison, J.H., Hayhurst, B.A., Lant, J., Nevers, M.B., Terrio, P.J., and Zimmerman, T.M., 2013, Developing and implementing predictive models for estimating recreational water quality at Great Lakes beaches: U.S. Geological Survey Scientific Investigations Report 2013-5166, 68 p. [Also available at $\mathrm{https}$ //doi.org/10.3133/sir20135166.]

Francy, D.S., Graham, J.L., Stelzer, E.A., Ecker, C.D., Brady, A.M.G., Struffolino, P., and Loftin, K.A., 2015, Water quality, cyanobacteria, and environmental factors and their relations to microcystin concentrations for use in predictive models at Ohio Lake Erie and inland lake recreational sites, 2013-14: U.S. Geological Survey Scientific Investigations Report 2015-5120, 58 p., 2 appendixes, accessed September 2019 at https://doi. org/10.3133/sir20155120.

Rantala, A., Rajaniemi-Wacklin, P., Lyra, C., Lepistö, L., Rintala, J., Mankiewicz-Boczek, J., and Sivonen, K., 2006, Detection of microcystin-producing cyanobacteria in Finnish lakes with genus-specific microcystin synthetase gene E (mcyE) PCR and associations with environmental factors: Applied and Environmental Microbiology, v. 72, no. 9, p. 6101-6110. [Also available at https://doi.org/10.1128/AEM.01058-06.]

U.S. Environmental Protection Agency [EPA], 2019, Environmental Modeling Community of Practice - Virtual Beach (VB): U.S. Environmental Protection Agency web page, accessed September 2019 at https://www.epa.gov/ceam/virtual-beach-vb.

U.S. Geological Survey [USGS], 2019, NowCast status: U.S. Geological Survey web page, accessed September 2019 at https://ny.water.usgs.gov/maps/nowcast/

\section{For more information, contact the USGS}

Ohio: Donna Francy and Amie Brady (dsfrancy@usgs.gov, amgbrady@usgs.gov)

Pennsylvania: Tammy Zimmerman (tmzimmer@usgs.gov)

New York: Guy Foster (gfoster@usgs.gov)

Michigan: Natasha Isaacs (nisaacs@usgs.gov)

For more information about this publication, contact:

Director, Ohio-Kentucky-Indiana Water Science Center

U.S. Geological Survey

6460 Busch Boulevard, Suite 100

Columbus, $\mathrm{OH} 43229$

614-430-7700

For additional information, visit: https://www.usgs.gov/centers/oki-water

Publishing support provided by the Rolla Publishing Service Center 